Creative commons User License: CC BY-NC-ND

Abstracted by: EBSCOhost, Electronic Journals Service (EJS),

Google Scholar, Directory of Open Access Journals (DOAJ),

Journal Seek, Scientific Commons,

Food and Agricultural Organization (FAO), CABI and Scopus
Journal of Agricultural Extension

Vol. 21 (1) February, 2017

ISSN(e): 24086851; ISSN(Print); 1119944X

http://journal.aesonnigeria.org

http://www.ajol.info/index.php/jae

Email: editorinchief@aesonnigeria.org

\title{
Socio-economic Determinants of Domestic Violence Suffered by Rural Women Crop Farmers in Imo State
}

http://dx.doi.org/10.4314/jae.v21i1.13

\section{Ifeanyi-obi, C.C.}

Department of Agricultural Economics and Extension, University of Port Harcourt, Rivers State

Email: clara.ifeanyi-obi@uniport.edu.ng

Phone: 0803339705/08025888119

\section{Agumagu, A.C.}

Department of Agricultural Economics and Extension, University of Port Harcourt, Rivers State

Email: acetee@yahoo.com

Phone: 08159287266

\section{Iromuanya, $\mathbf{P}$.}

Department of Agricultural Economics and Extension, University of Port Harcourt.

Email: iromuanyaprisca@gmail.com

Phone: 07066816503

\section{Abstract}

The study identified the socio-economic determinants of domestic violence suffered by rural women crop farmers in Orlu agricultural zone of Imo State, Nigeria. Multistage sampling procedure was used to select 80 rural women crop farmers for the study. Data were collected using structured interview schedule and analyzed with both descriptive and inferential statistical tools. Findings show that out of the fortytwo variables used to capture the nature of domestic violence suffered by women in the study area, only eight reached the cutoff point of 2.50. The major causes of domestic violence identified by the study were disagreement over money $(\overline{\boldsymbol{x}}=3.0)$, failure to perform domestic chores $(\overline{\boldsymbol{x}}=2.7)$, disobedience to husband $(\overline{\boldsymbol{x}}=2.7)$ and sharing marital problems with friends $(\overline{\boldsymbol{x}}=2.7)$. Respondent's age, duration of marriage, educational status, religion, household size and number of wives were the major determinants of domestic violence. It was recommended that a reorientation be given to the men in the area to enlighten them more on the negative effects of domestic violence.

Key Words: Socio-economic determinants of women voilence, women, domestic violence.

\section{Introduction}

The contributions of women to food security in Nigeria cannot be overemphasized.

Despite some exclusion placed on women either by culture or policies, women have 
Creative commons User License: CC BY-NC-ND

Abstracted by: EBSCOhost, Electronic Journals Service (EJS), Google Scholar, Directory of Open Access Journals (DOAJ), Journal Seek, Scientific Commons,

Food and Agricultural Organization (FAO), CABI and Scopus
Journal of Agricultural Extension

Vol. 21 (1) February, 2017

ISSN(e): 24086851; ISSN(Print); 1119944X

http://journal.aesonnigeria.org

http://www.ajol.info/index.php/jae

Email: editorinchief@aesonnigeria.org

continued to contribute immensely to food production in the country. The report of the women and children affairs (Ministry of Women and Children Affairs Ghana, 2012) noted that globally rural women contribute through different livelihood strategies to lift their families and communities out of poverty and hunger but their potential to do so is limited by multiple and diverse constraints due to the systematic and structural gender disparities that prevent them from enjoying their economic and other rights. In an agrarian household economy, women's labor is essential to the survival of the family, which is the primary economic unit of production, (Freeman, 1995). Unfortunately, several women are faced with some forms of domestic violence while performing their roles as the homemaker. This domestic violence constitutes a militating factor against their effective production.

World Health Organization (WHO, 2013), defined domestic violence as the range of sexually, psychologically and physically coercive acts used against adult and adolescent women by current or former male intimate partners. This often leaves the victim living in constant fear, pains and depression. In severe cases, it can erode a woman's sense of self-worth and can be incredibly harmful to overall mental and physical well-being (Women's' health, 2013). It also lowers the general soundness and fitness of the victim's performance and productivity.

Women make essential contribution to agriculture especially in developing countries, (The role of women in agriculture, 2011). At the same time, the rate of domestic violence against women is also highest in Africa, the Middle East and Southeast Asia, with $37 \%$ of women experiencing physical or sexual violence from a partner at some point in their lifetime (WHO, 2013). This goes a long way to showcase the importance of women in the agricultural sector and the unfortunate drawback facing their effectiveness in the sector. Agriculture as a business enterprise requires an individual's initiative and vitality. Often, these women who have been domestically abused by their close ones, lack the energy and enthusiasm required for an effective agricultural production. Generally, domestic violence lowers the overall health of the women (victims) by destabilizing the peaceful co-existence among their family members. The farm family is affected because even the children from such homes 
Creative commons User License: CC BY-NC-ND

Abstracted by: EBSCOhost, Electronic Journals Service (EJS),

Google Scholar, Directory of Open Access Journals (DOAJ),

Journal Seek, Scientific Commons,

Food and Agricultural Organization (FAO), CABI and Scopus
Journal of Agricultural Extension

Vol. 21 (1) February, 2017

ISSN(e): 24086851; ISSN(Print); 1119944X

http://journal.aesonnigeria.org

http://www.ajol.info/index.php/jae

Email: editorinchief@aesonnigeria.org

suffer psychologically and may grow to become victims or perpetrators of domestic violence. This domestic violence might be in the form of abuse, insult or injury and may be physical, sexual, verbal/emotional or psychological. Some of the factors that contribute to it include alcoholism, alleged misconducts, cultural norm (some cultures believes that women are men's property and thus, should be meek or else, get penalized) (Prem, 2012).

In Orlu agricultural zone of Imo State, the story is not different from what is happening in other parts of the world in respect of domestic violence. It has been observed that many women suffer varying dimensions of domestic violence especially emotional/psychological violence. Traditionally in the area, it is widely believed that a married woman is a property of the husband and as such could be used by him as he deems fit. Also, women who divorce their husband are treated with less respect in the culture with the belief that they are not responsible enough to maintain their marital homes. This results in many women silently bearing untold violence in the hands of their husband in order to maintain their homes. They prefer to suffer in silence than to divorce and be seen as an irresponsible person who cannot maintain her marital home. This affects many of them in their different activities as their concentration and productivity is affected. It is necessary for the different stakeholders in the zone to study and understand the nature of domestic violence experienced by these women and also identify possible ways of reducing this vice in the area.

Therefore, bearing in mind the importance of the agricultural sector to nation's economy and contributing to the alleviation of domestic violence in the rural communities of the nation, this study identified the socio-economic determinants of domestic violence suffered by rural women crop farmers in Orlu agricultural zone of Imo State. Specifically, it described the socio- economic characteristics of the respondents and examined the nature of domestic violence suffered by the women in the study area. 
Creative commons User License: CC BY-NC-ND

Abstracted by: EBSCOhost, Electronic Journals Service (EJS),

Google Scholar, Directory of Open Access Journals (DOAJ),

Journal Seek, Scientific Commons,

Food and Agricultural Organization (FAO), CABI and Scopus
Journal of Agricultural Extension

Vol. 21 (1) February, 2017

ISSN(e): 24086851; ISSN(Print); 1119944X

http://journal.aesonnigeria.org

http://www.ajol.info/index.php/jae

Email: editorinchief@aesonnigeria.org

\section{Methodology}

The study was conducted in Orlu Agricultural Zone (OAZ) of Imo State. Imo State is among the South-eastern states in Nigeria. The major occupation of the people of the state is farming. The population of the study comprises of registered rural women-crop farmers in OAZ. To ensure that women from all communities in the zone were represented in the study, multi-stage sampling procedure was used for the study. In the first stage, four extension blocks were randomly selected from 10 blocks in the zone. The second stage involved random selection of two circles from each of the selected blocks giving a total of eight circles. The last stage involved random selection of ten women-crop farmers from each of the selected eight circles giving a total of eighty women crop farmers for the study. However only 76 copies of the interview schedule were used for analysis, four respondents did not properly attend to the questionnaire hence was not valid for analysis.

Data were collected through the use of structured interview schedule. Data was analyzed using descriptive statistical tools namely frequency distribution, mean and percentages. The nature of domestic violence faced by rural women and reasons for domestic violence were captured using a 4point-Likert type scale of Strongly Agree (4), Agree (3), Disagree (2), and Strongly Disagree (1). A midpoint of 2.50 was obtained and based on this, decision rule was that any mean score greater than or equal to 2.50 implies agreement with the nature of domestic violence, and any mean score less than 2.50 implies disagreement.

The socio-economic determinants of domestic violence were identified using an ordinary least square multiple regression analysis.

The Model specification is implicitly stated as follows:

$Y=f\left(X_{1}, X_{2}, X_{3}, X_{4}, X_{5}, X_{6}, X_{7}, X_{8}, e\right)$

Where $Y=$ pooled index of nature of domestic violence suffered by women crop farmers in the study area measured with a four point Likert-type scale of strongly agree $=4$, agree $=3$, disagree $=2$ and strongly disagree $=1$

$X_{1}=$ Age (measured in years)

$\mathrm{X}_{2}=$ Duration of marriage (measured in years) 
Creative commons User License: CC BY-NC-ND

Abstracted by: EBSCOhost, Electronic Journals Service (EJS),

Google Scholar, Directory of Open Access Journals (DOAJ),

Journal Seek, Scientific Commons,

Food and Agricultural Organization (FAO), CABI and Scopus
Journal of Agricultural Extension

Vol. 21 (1) February, 2017

ISSN(e): 24086851; ISSN(Print); 1119944X

http://journal.aesonnigeria.org

http://www.ajol.info/index.php/jae

Email: editorinchief@aesonnigeria.org

$\mathrm{X}_{3}=$ Educational qualification (No of years in school)

$\mathrm{X}_{4}=$ major occupation (Farming $=1$, Non-farming $=2$ )

$\mathrm{X}_{5}=$ Monthly income (measured in naira)

$\mathrm{X}_{6}=$ Religion (Christianity $=1$, traditional $=2$ )

$X_{7}=$ No of biological children (No of children given birth to by the women)

$\mathrm{X}_{8}=$ Household size (no of persons per household)

$\mathrm{X}_{9}=$ use of modern contraceptive $(\mathrm{No}=1$, Yes $=1)$

$\mathrm{X}_{10}=$ Number of wives (No of wives your spouse married)

$\mathrm{e}=$ error term

The relationship between the dependent and each of the independent variables were examined using the four functional forms: linear, semi-log, exponential and doublelog. A lead equation was chosen based on the magnitude of multiple determination (R2) and statistical significance of variables.

Linear: $\mathrm{Y}_{=} \mathrm{B}_{0}+\mathrm{B}_{1} \mathrm{X}_{1}+\mathrm{B}_{2} \mathrm{X}_{2}+\mathrm{B}_{3} \mathrm{X}_{3}+\mathrm{B}_{4} \mathrm{X}_{4}+\mathrm{B}_{5} \mathrm{X}_{5}+\mathrm{B}_{6} \mathrm{X}_{6}+\mathrm{B}_{7} \mathrm{X}_{7}+\mathrm{B}_{8} \mathrm{X}_{8}+\mathrm{B}_{9} \mathrm{X}_{9}+$ $\mathrm{B}_{10} \mathrm{X}_{10}+\mathrm{e}$

Semi-Log: $Y=B_{0}+B_{1} \log X_{1}+B_{2} \log X_{2}+B_{3} \log X_{3}+B_{4} \log X_{4}+B_{5} \log X_{5}+B_{6} \log X_{6}+$

$B_{7} \log X_{7}+B_{8} \log X_{8}+B 9 \log X_{9}+B_{10} \log _{9} X_{10}+e$

Exponential: $\log Y=B_{0}+B_{1} X_{1}+B_{2} X_{2}+B_{3} X_{3}+B_{4} X_{4}+B_{5} X_{5}+B_{6} X_{6}+B_{7} X_{7}+B_{8} X_{8}+$ $\mathrm{B} 9 \mathrm{X} 9+\mathrm{B}_{10} \mathrm{X}_{10}+\mathrm{e}$

Double Log: $\log Y=B_{0}+B_{1} \log X_{1}+B_{2} \log X_{2}+B_{3} \log X_{3}+B_{4} \log X_{4}+B_{5} \log X_{5}+B_{6}$ $\log X_{6}+B_{7} \log X_{7}+B_{8} \log X_{8}+B_{9} L_{o g} X_{9}+B_{10} L_{0 g} X_{10}+e$

$\mathrm{B}_{\mathrm{o}}=$ intercept

$B_{1}, B_{2} \ldots B_{8}=$ estimated coefficients

\section{Results and Discussions}

\section{Socio-economic Characteristics}

Results show that $68.5 \%$ of the women were 40 years and below. This reveals that the majority of the women used for the study were middle-aged women who could be said to be still in their productive and child bearing age. As such any form of domestic violence experienced may significantly affect their productivity. 
Creative commons User License: CC BY-NC-ND

Abstracted by: EBSCOhost, Electronic Journals Service (EJS), Google Scholar, Directory of Open Access Journals (DOAJ), Journal Seek, Scientific Commons,

Food and Agricultural Organization (FAO), CABI and Scopus
Journal of Agricultural Extension

Vol. 21 (1) February, 2017

ISSN(e): 24086851; ISSN(Print); 1119944X

http://journal.aesonnigeria.org

http://www.ajol.info/index.php/jae

Email: editorinchief@aesonnigeria.org

Results also show that the majority (81.4\%) of the women were legally married while the remaining $18.6 \%$ were not legally married.

As regards duration of marriage, it was shown that, $88.7 \%$ of the women had spent at least 8years in their marriage. Approximately, $71 \%$ of the women had at most secondary school education while $7.9 \%$ had no formal education. This is not surprising as rural inhabitants do not encourage the education of their women, (Taiwo, 2012). They opined that women should be married off to take care of their husbands and children. Only $23.3 \%$ of the women earned above N20, 000 on monthly basis. The majority (52.7\%) had more than five biological children. This revealed that women in the rural area still indulge in bearing high number of children as against most urban families who bear lesser number of children. The majority $(77.6 \%)$ of the women maintained a household size of at least 10 persons while $51.3 \%$ do not use modern contraceptive. It was also shown that the major occupation of their spouses is non - agricultural activities (58.4\%). This revealed that farming activities in most rural areas were spearheaded by women. Most men who indulge in agricultural activities in this area had other major means of income as such use agricultural activities as a supplementary means of income generation. This showcases more the need to improve the production capacity of rural women as they are the major stakeholders in agricultural production in the rural areas. Furthermore, findings show that the majority (85.5\%) of the respondents have spouses that are older than them while about $82.9 \%$ have age difference of at least 10 years from those of their spouses. It was further shown that the majority $(76.3 \%)$ of the women were into monogamy, this may not be surprising as the area is dominated by Christians (92.1\%) whose religion do not accept polygamy. 
Creative commons User License: CC BY-NC-ND

Abstracted by: EBSCOhost, Electronic Journals Service (EJS), Google Scholar, Directory of Open Access Journals (DOAJ), Journal Seek, Scientific Commons,

Food and Agricultural Organization (FAO), CABI and Scopus
Journal of Agricultural Extension

Vol. 21 (1) February, 2017

ISSN(e): 24086851; ISSN(Print); 1119944X

http://journal.aesonnigeria.org

http://www.ajol.info/index.php/jae

Email: editorinchief@aesonnigeria.org

Table 1: Socio-economic characteristics of respondents

Characteristics Mean

Percentage

$\begin{array}{lc}\text { Age (years) } & 37 \\ <30 & \end{array}$

\section{7}

$31-40$

$41-50$

44.8

Above 50

23.7

Marital status

Not legally married

Married

Duration of marriage (years)

10

$<7$

8-13

34

14-19

Above 20

Educational status

No formal education

Primary

Secondary

48.7

Tertiary

Major occupation

Farming

Non-farming

$<5,000$

$5,000-12,000$

45.5

$12,001-20,000$

27.3

Above 20,000

23.3

No of your biological child

5

$0-2$

19.7

3-5

27.6

Above 5

Household size

38.1

$1-5$

7

39.5

$6-10$

Use of modern contraceptives

Major Occupation of your spouse

Agricultural

Non-Agricultural

Myself

Age difference between you and your spouse

$1-5$

7

6-10

Above 10

Christianity

Traditional

How many wives does your husband have? 
Creative commons User License: CC BY-NC-ND

Abstracted by: EBSCOhost, Electronic Journals Service (EJS),

Google Scholar, Directory of Open Access Journals (DOAJ),

Journal Seek, Scientific Commons,

Food and Agricultural Organization (FAO), CABI and Scopus
Journal of Agricultural Extension

Vol. 21 (1) February, 2017

ISSN(e): 24086851; ISSN(Print); 1119944X

http://journal.aesonnigeria.org

http://www.ajol.info/index.php/jae

Email: editorinchief@aesonnigeria.org

\section{Nature of Domestic Violence faced by Women in Orlu Agricultural Zone of Imo}

State.

All $(100 \%)$ the rural women consented that women suffer varying forms of domestic violence in the hands of their spouses. The nature of domestic violence faced by the rural women in the area was categorized into four namely: physical violence, emotional/psychological violence, financial/economic violence and sexual violence. Out of the 42 variables used to capture nature of domestic violence suffered by women in the study area, only eight reached the cutoff point of 2.50. These include; am threatened with words and shouts $(M=2.5)$, he humiliates me in front of friends, family and strangers $(M=2.5)$, he calls me names and uses abusive language $(M=$ 2.7), am often criticized and humiliated (2.5), he uses disproportionate anger or yelling to intimidate me $(M=2.7)$, he irrationally blames me for everything $(2.7)$, he withholds affection, approval or appreciation as a punishment $(\mathrm{M}=2.7)$ and he threatens me with weapons (2.5). The result showed that though women are physically abused, the most prominent form of abuse experienced by women in the study area fall under emotional/psychological violence. This agrees with the findings of Koenig et.al., (2003), which identified verbal violence as the most form of violence experienced by women in rural Uganda. Men are known to earn higher income than the women in most families in Nigeria, this may account for the low mean values of variable under financial violence as some men may not bother their wives since they earn higher income than them. 
Creative commons User License: CC BY-NC-ND

Abstracted by: EBSCOhost, Electronic Journals Service (EJS), Google Scholar, Directory of Open Access Journals (DOAJ), Journal Seek, Scientific Commons,

Food and Agricultural Organization (FAO), CABI and Scopus
Journal of Agricultural Extension

Vol. 21 (1) February, 2017

ISSN(e): 24086851; ISSN(Print); 1119944X

http://journal.aesonnigeria.org

http://www.ajol.info/index.php/jae

Email: editorinchief@aesonnigeria.org

Table 2: Mean distribution of women by the nature of domestic violence faced.

\begin{tabular}{|c|c|c|}
\hline Nature of domestic violence experienced by women & Mean & Standard deviation \\
\hline \multicolumn{3}{|l|}{ Physical Violence } \\
\hline $\begin{array}{l}\text { Hitting, beating, choking, pushing, slapping, kicking, pulling hair, biting, punching, backhanding, arm- } \\
\text { twisting, shoving or burning }\end{array}$ & 2.1 & 0.817 \\
\hline Throwing and hitting me with objects & 2.1 & 0.926 \\
\hline Locks me out of the house & 2.0 & 0.765 \\
\hline I am denied medical help/attention & 2.1 & 0.692 \\
\hline I am denied basic physical needs(eating and sleeping) & 2.2 & 0.801 \\
\hline He shoves and drags me around the house & 2.2 & 0.901 \\
\hline He locks me up/starve me and the kids & 2.3 & 0.954 \\
\hline \multicolumn{3}{|l|}{ Emotional/psychological Violence } \\
\hline He threatens me with words/shouts & $2.5^{\star}$ & 0.945 \\
\hline He humiliates me in front of friends, family or strangers & $2.5^{\star}$ & 0.901 \\
\hline He calls me names and uses abusive language & $2.7^{*}$ & 0.977 \\
\hline I am often criticized and humiliated & $2.5^{\star}$ & 0.931 \\
\hline He uses disproportionate anger or yelling to intimidate me & $2.7^{*}$ & 0.902 \\
\hline He irrationally blames me for everything & $2.7^{\star}$ & 0.861 \\
\hline He withholds affection, approval or appreciation as a punishment & $2.7^{*}$ & 0.866 \\
\hline I suffer obsessive jealousy and accusation of unfaithfulness & 2.3 & 0.870 \\
\hline He uses intimate knowledge of me to abuse me & 2.1 & 0.943 \\
\hline He threatens to harm himself or commit suicide just to punish me & 2.2 & 0.922 \\
\hline He tells false stories about me & 2.1 & 0.864 \\
\hline He unnecessarily monitors my phone calls, mails or visits & 2.2 & 0.820 \\
\hline He insults, threatens or assaults my friends or family; driving them away & 2.2 & 0.771 \\
\hline \multicolumn{3}{|l|}{ Financial/economic violence } \\
\hline He intimidates and extorts my money & 2.1 & 0.926 \\
\hline He forbids me to work & 1.9 & 0.776 \\
\hline He jeopardizes my employment by negative tactics example; creating conflict with co-workers, & 1.9 & 0.812 \\
\hline supervisors or clients; creating scenes with co-workers; forcing me to miss work through threats & 1.9 & \\
\hline He refuses to work yet contributes to expenses & 1.9 & 0.769 \\
\hline He denies me access to shared resources, including bank accounts and common property & 2.1 & 0.786 \\
\hline He forces me to pay for all expenses including rent, food and utilities & 2.0 & 0.879 \\
\hline He steals and sells my properties as a means of affecting my financial situation & 2.0 & 0.816 \\
\hline He destroys my properties as a means of affecting my financial situation & 2.0 & 0.886 \\
\hline He seizes my credit cards, money or Cheque book & 2.0 & 0.915 \\
\hline Sexual violence & 2.2 & \\
\hline He makes caricature of my body/appearance & 2.1 & 0.869 \\
\hline He forces sex or sexual actions on me without my consent (marital rape) & 2.2 & 0.988 \\
\hline He refuses to comply with my request for safe sex & 2.1 & 0.984 \\
\hline He forces me to have sex with others & 2.0 & 0.909 \\
\hline He violates our agreements for monogamy by having sex with others & 2.3 & 0.946 \\
\hline He exposes me to sexually transmitted diseases by his reckless sex affairs & 2.3 & 0.839 \\
\hline He treats me as a sex object & 2.3 & 0.822 \\
\hline He criticizes my sexual performance or desirability & 2.3 & 0.901 \\
\hline He withholds sex from me as a punishment & 2.2 & 0.889 \\
\hline
\end{tabular}
- $\quad$ Agree Source: Field survey, 2013

\section{Reasons for Domestic Violence}

Table 3 shows that disagreement over money $(x=3.0)$ was the major reasons and cause of domestic violence. This is not surprising in a country where the economy is poor putting low income earners under undue stress and pressure. In the olden days, women from this area were not allowed to engage in other jobs outside family chores but now women engage in all kinds of work outside family chores in order to support their husbands in taking care of family needs. Despite this effort by women, the financial stress on the family is still much and most time brings quarrel between them and their spouses. 
Creative commons User License: CC BY-NC-ND

Abstracted by: EBSCOhost, Electronic Journals Service (EJS),

Google Scholar, Directory of Open Access Journals (DOAJ),

Journal Seek, Scientific Commons,

Food and Agricultural Organization (FAO), CABI and Scopus
Journal of Agricultural Extension

Vol. 21 (1) February, 2017

ISSN(e): 24086851; ISSN(Print); 1119944X

http://journal.aesonnigeria.org

http://www.ajol.info/index.php/jae

Email: editorinchief@aesonnigeria.org

Other reasons for domestic violence among women in the study area include failure to perform domestic duties ( $\bar{x}=2.7)$, disobedience to husband $(\bar{x}=2.7)$, sharing marital problems with friends $(\bar{x}=2.7)$. It was gathered from the women during the interview schedule that engaging in other jobs puts much stress on them and affects the level of commitment to family chores. Some of them said their jobs were even more tasking than their husbands own yet the man comes home and refuses to lend a helping hand in doing the family chores. According to the women, even in the farm work, the bulk of the work is done by them which weaken them. They also emphasize that their husbands were too secretive even to their own detriment. In times of family crisis, they would rather prefer to die in silence than to seek counseling from more matured couple, when they try to do it on their own for the betterment of the family, the end product is always severe beating from the husband. Refusal to have sex $(\bar{x}=2.6)$, disobedience to husbands elderly relations $(\bar{x}=2.6)$, doing things without his consent $(\overline{\boldsymbol{x}}=2.6)$, unnecessary extravagance with money $(\overline{\boldsymbol{x}}$ $=2.5)$, disagreement over number of children to have $(\bar{x}=2.5)$, disagreement over choice of friends $(\bar{x}=2.5)$, revealing the husband secret $(\bar{x}=2.5)$ and comparing my husband with more successful mates $(\bar{x}=2.6)$ were also some of the reasons for domestic violence in the study area.

It is a common belief in the study area and even in some African countries in general that a man alone does not marry his wife. Implying that the women owe every member of the husband's family due respect. According to the women in the study area, some husbands can condone disrespect from their wives but cannot overlook disrespect shown to the elderly member of their family by their wife. Also, refusal to have sex is one of the major causes of domestic violence in the study area. The women complained that their husbands do not take cognizance of their state; whether they are weak or not, they only want to satisfy their sex urge. Some of them who use natural way of family planning said that even when they are not in their safe period their husbands insist on having sex leading to unwanted pregnancy which the husband will insist on abortion. Failure to carry out the abortion always results in severe beating and further rejection from their husbands. 
Creative commons User License: CC BY-NC-ND

Abstracted by: EBSCOhost, Electronic Journals Service (EJS), Google Scholar, Directory of Open Access Journals (DOAJ), Journal Seek, Scientific Commons,

Food and Agricultural Organization (FAO), CABI and Scopus
Journal of Agricultural Extension

Vol. 21 (1) February, 2017

ISSN(e): 24086851; ISSN(Print); 1119944X

http://journal.aesonnigeria.org

http://www.ajol.info/index.php/jae

Email: editorinchief@aesonnigeria.org

Table 3: Mean distribution on reasons for domestic violence

\begin{tabular}{lll}
\hline Reasons for domestic violence & Mean & $\begin{array}{l}\text { Standard } \\
\text { deviation }\end{array}$ \\
\hline Disagreements over money & 3.0 & $0.825^{\star}$ \\
& & \\
Failure to perform domestic chores & 2.7 & $0.746^{\star}$ \\
Refusal to have sex & 2.6 & $0 . .934^{*}$ \\
Use of contraception without his permission & 2.4 & 0.938 \\
Disobedience to husbands' elderly relations & 2.6 & $0.761^{*}$ \\
Disobedience to husband & 2.7 & $0.917^{*}$ \\
Being suspected of infidelity & 2.4 & 0.985 \\
Insistence on the use of contraceptives/condom & 2.1 & 0.888 \\
Suspected of being HIV positive & 2.1 & 0.903 \\
Sharing marital problems with friends & 2.7 & $0.836^{*}$ \\
Doing things without his consent & 2.6 & $0.936^{*}$ \\
Unnecessary extravagance with money & 2.5 & $0.917^{*}$ \\
Childlessness & 2.2 & 0.994 \\
Inability to have male children & 2.2 & 0.950 \\
Disagreement over number of children to have & 2.5 & $0.986^{*}$ \\
Disagreement over choice of friends & 2.5 & $0.756^{*}$ \\
Revealing the man's secret discussion with me & 2.5 & $0.791^{*}$ \\
Rudely comparing my husband with more successful mates & 2.6 & $0.875^{\star}$ \\
Not treating the man's family well & 2.3 & 0.780 \\
Over catering for members of her fathers` family & 2.3 & 0.817 \\
& & \\
\hline
\end{tabular}

- Agree Source: Field survey 2013

\section{Socio-economic Determinants of Domestic Violence Among Rural Women.}

Table 4 reveals that $39.1 \%$ of the variation in domestic violence experienced by women in the study area could be explained by their socio-economic characteristics in the equation.

The result indicated that two (household size and no of wives) of the ten independent variables correlated positively and significantly with nature of domestic violence experienced by women in the area while four (age, duration of marriage, religion and educational status) correlated negatively and significantly with the nature of domestic violence. The coefficient of determination for age and duration of marriage correlated negatively with the nature of domestic violence experienced by women in the study are with a t-value of -6.144 and -7.003 , respectively which was significant at both 0.01 and 0.05 level of probability. This could imply that as the couple advance in both their chronological age and duration of marriage they tend to understand and 
Creative commons User License: CC BY-NC-ND

Abstracted by: EBSCOhost, Electronic Journals Service (EJS), Google Scholar, Directory of Open Access Journals (DOAJ), Journal Seek, Scientific Commons,

Food and Agricultural Organization (FAO), CABI and Scopus

\author{
Journal of Agricultural Extension \\ Vol. 21 (1) February, 2017 \\ ISSN(e): 24086851; ISSN(Print); 1119944X \\ http://journal.aesonnigeria.org \\ http://www.ajol.info/index.php/jae \\ Email: editorinchief@aesonnigeria.org
}

tolerate themselves better thereby reducing the level of domestic violence. Educational status also correlated negatively and significantly with the nature of domestic violence with a t-value of -6.377 which was significant at both 0.01 and 0.05 level of probability. This could imply that the more educated couple experience less domestic violence as education exposes them to more meaningful ways of managing conflicts in their homes. Also, religion was found to correlate negatively and significantly with the nature of domestic violence with a t-value of -3.167 which was significant at 0.05 probability level. The socio-economic characteristics show that approximately $92 \%$ of the women used for this study were Christians. Christianity upholds peaceful co-existence of couple in marriage and helps her members through teachings and admonishments to maintain peaceful homes. This may be the reason why the level of domestic violence reduces as the women increase their religious inclinations. Household size and number of wives were found to correlate positively and significantly with the nature of domestic violence with t-values of 5.859 and 4.845 , respectively. Increase in these two factors will increase responsibility as the man will have more people to feed and cater for. Also there will be personalities in the house to understand and tolerate. The probability of experiencing domestic violence may also increase. 
Creative commons User License: CC BY-NC-ND

Abstracted by: EBSCOhost, Electronic Journals Service (EJS),

Google Scholar, Directory of Open Access Journals (DOAJ),

Journal Seek, Scientific Commons,

Food and Agricultural Organization (FAO), CABI and Scopus
Journal of Agricultural Extension

Vol. 21 (1) February, 2017

ISSN(e): 24086851; ISSN(Print); 1119944X

http://journal.aesonnigeria.org

http://www.ajol.info/index.php/iae

Email: editorinchief@aesonnigeria.org

Table 4: Socio-economic determinants of domestic violence among women

\begin{tabular}{|c|c|c|c|c|}
\hline \multirow[t]{2}{*}{ Variable } & \multicolumn{2}{|c|}{ Functional form } & \multirow[b]{2}{*}{ Double Log } & \multirow[b]{2}{*}{ Exponential } \\
\hline & Linear & Semi- log & & \\
\hline Constant & $\begin{array}{l}21.487 \\
(5.188)^{* *}\end{array}$ & $\begin{array}{l}48.403 \\
(3.165)^{\star *}\end{array}$ & $\begin{array}{l}.254 \\
(8.912)^{\star *}\end{array}$ & $\begin{array}{l}.113 \\
(18.338)^{* *}\end{array}$ \\
\hline Age & $\begin{array}{l}-.394 \\
(-6.144)^{\star *}\end{array}$ & $\begin{array}{l}-.040 \\
(-4.264)^{\star *}\end{array}$ & $\begin{array}{l}-.040 \\
(-4.111)^{\star *}\end{array}$ & $\begin{array}{l}.024 \\
(.160)\end{array}$ \\
\hline Duration of marriage & $\begin{array}{l}-.167 \\
(-7.003)^{\star *}\end{array}$ & $\begin{array}{l}-.081 \\
(-5.515)^{\star *}\end{array}$ & $\begin{array}{l}-.076 \\
-3.485)^{\star *}\end{array}$ & $\begin{array}{l}-.163 \\
(-2.976)^{\star *}\end{array}$ \\
\hline Educational status & $\begin{array}{l}-.178 \\
(-6.377)^{\star *}\end{array}$ & $\begin{array}{l}-.189 \\
(-1.529)\end{array}$ & $\begin{array}{l}-.190 \\
(6.538)^{* *}\end{array}$ & $\begin{array}{l}-.180 \\
(-5.394)^{\star *}\end{array}$ \\
\hline Major occupation & $\begin{array}{l}0.045 \\
(.391)\end{array}$ & $\begin{array}{l}.056 \\
(.486)\end{array}$ & $\begin{array}{l}.060 \\
(.520)\end{array}$ & $\begin{array}{l}.051 \\
(.441)\end{array}$ \\
\hline Monthly income & $\begin{array}{l}-.217 \\
(-1.638)\end{array}$ & $\begin{array}{l}-.154 \\
(1.225)\end{array}$ & $\begin{array}{l}-.133 \\
(-1.055)\end{array}$ & $\begin{array}{l}-.198 \\
(-1.494)\end{array}$ \\
\hline Religion & $\begin{array}{l}-.132 \\
(-3.167)^{*}\end{array}$ & $\begin{array}{l}110 \\
(2.974)^{\star *}\end{array}$ & $\begin{array}{l}.099 \\
(.876)\end{array}$ & $\begin{array}{l}120 \\
(4.058)^{\star *}\end{array}$ \\
\hline No of biological children & $\begin{array}{l}.085 \\
(.716)\end{array}$ & $\begin{array}{l}-.124 \\
(-1.063)\end{array}$ & $\begin{array}{l}-.164 \\
(-1.407)\end{array}$ & $\begin{array}{l}-1.052 \\
(.297)\end{array}$ \\
\hline Household size & $\begin{array}{l}.206 \\
(5.859)^{\star *}\end{array}$ & $\begin{array}{l}-.216 \\
(-1.931)\end{array}$ & $\begin{array}{l}.209 \\
(2.873)^{\star *}\end{array}$ & $\begin{array}{l}-.200 \\
(-1.798)\end{array}$ \\
\hline Use of modern contraceptive & $\begin{array}{l}.193 \\
(1.729)\end{array}$ & $\begin{array}{l}.200 \\
(1.772)\end{array}$ & $\begin{array}{l}.171 \\
(1.520)\end{array}$ & $\begin{array}{l}.167 \\
(1.494)\end{array}$ \\
\hline Number of wives & $\begin{array}{l}.205 \\
(4.845)^{\star *}\end{array}$ & $\begin{array}{l}187 \\
(3.644)^{* *}\end{array}$ & $\begin{array}{l}.209 \\
(5.841)^{* *}\end{array}$ & $\begin{array}{l}.224 \\
(2.013)\end{array}$ \\
\hline $\mathrm{R}^{2}$ & 0.391 & 0.328 & 0.232 & 0.231 \\
\hline F-Stat & 10.895 & 10.561 & 7.230 & 7.507 \\
\hline Prob (F-Stat) & 0.000 & 0.000 & 0.000 & 0.001 \\
\hline
\end{tabular}

Figures in the first row are regression Coefficients t-ratios are in parentheses. ${ }^{*} \mathrm{P} \leq 0.05 ;{ }^{* *} \mathrm{P} \leq 0.01$

Source: Field data, 2013

\section{Conclusion and Recommendations}

Findings of the study indicated that duration of marriage, educational status, religion, household size, religion, number of wives and age are the socio-economic determinants of domestic violence in the study area. Also, emotional/psychological violence was found to be the most prominent type of domestic violence suffered by women in the study area. Religious bodies should be encouraged to educate their members on effective ways of handling marital problem as well as the detrimental effects of domestic violence. This could be done through marriage workshops, seminars and marriage classes normally held for intending couples. Also, government and NGOs through television and radio programme, workshops and seminars should sensitize the men on the detrimental effects of marrying many 
Creative commons User License: CC BY-NC-ND

Abstracted by: EBSCOhost, Electronic Journals Service (EJS), Google Scholar, Directory of Open Access Journals (DOAJ), Journal Seek, Scientific Commons,

Food and Agricultural Organization (FAO), CABI and Scopus
Journal of Agricultural Extension

Vol. 21 (1) February, 2017

ISSN(e): 24086851; ISSN(Print); 1119944X

http://journal.aesonnigeria.org

http://www.ajol.info/index.php/jae

Email: editorinchief@aesonnigeria.org

wives and maintaining large household size as these increase the occurrence of domestic violence.

\section{References}

Ellen Boneparth (1982). Women Power and Policy. pp. 265. Pergamon Press, New York Retrieved March, $16^{\text {th }} 2014$.

Freeman Norway (1995). Womens' Contribution Towards a Sustainable agriculture. pp 47, McGill publications New Delhi.

Koenig, M. A., Tom Lutalo, Feng Zhao, Fred Nalugoda, Fred Wabwiremangan, Noah Kiwanuka, Jennifer Wagman, David Serwadda, Maria Wawer \& Ron Gray (2003). Domestic violence in rural Uganda: Evidence from a community-based study, Bulletin of the World Health Organization, 81:53-60, http://www.who.int/bulletin/Koenig0103.pdf Retrieved Jan, $22^{\text {nd }} 2014$.

Ministry of Women and Children Affairs (MOWAC) Ghana (year). Rural women and MDGs 1 and 3. Ghana's success and challenges. Technical paper on Ghana's Side Event $56^{\text {th }}$ CSW, New York. $29^{\text {th }}$ Feb, 2012 Pp.2.

Prem Chowdhry (2012). Reduction of violence against women: property ownership and economic independence in rural Haryana. United Nations Entity for Gender Equality and the Empowerment of women. http://clientdisplay.com/unwomen/assets/ViolenceProperty-Rights2.pdf Retrieved Jan, 2014.

Taiwo, P.A.J. (2012) Attitude of women towards family planning in selected rural communities of Ibadan. African Journal of psychological study of social sciences, 15(1).

The role of women in agriculture. WSA working paperNo.11-02, March 2011. http://www.fao.org/docrep/013/am307e/am307e00.pdf Assessed, 14 ${ }^{\text {th }}$ October 2016

World Health Organization (WHO) (1997). Violence against women: A priority healthissue. http://www.who.int/violence injury prevention/media/en/154.pdf Retrieved Nov, $12^{\text {th }}$ 2013. 